Document downloaded from:

http://hdl.handle.net/10251/99654

This paper must be cited as:

Pla, L.; Xifre Perez, E.; Ribes, A.; Aznar, E.; Marcos Martínez, MD.; Marsal, L.; MartínezMáñez, R.... (2017). A Mycoplasma Genomic DNA Probe using Gated Nanoporous Anodic Alumina. ChemPlusChem. 82(3):337-341. doi:10.1002/cplu.201600651

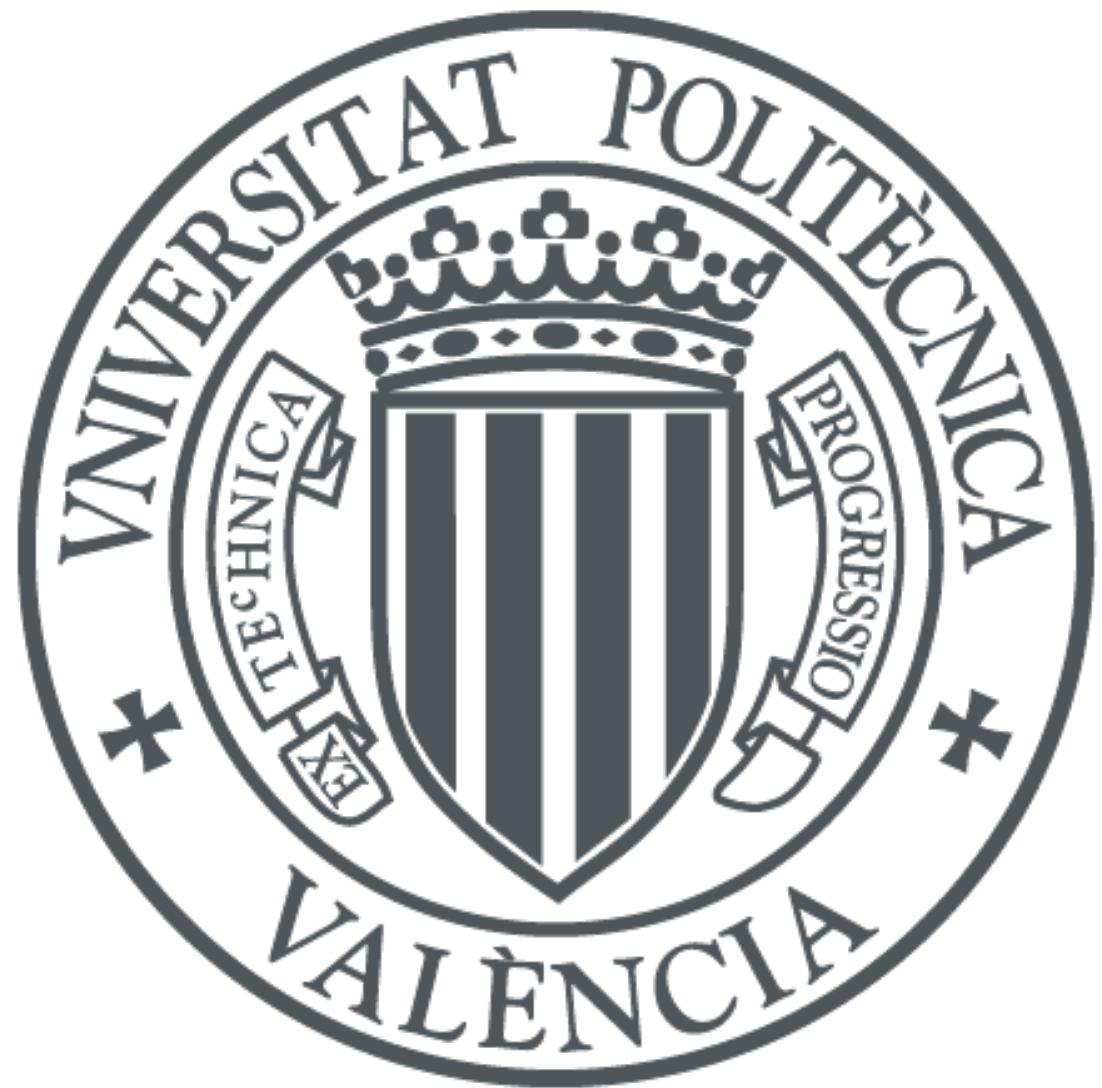

The final publication is available at

https://doi.org/10.1002/cplu.201600651

Copyright John Wiley \& Sons

Additional Information 


\title{
A Mycoplasma genomic DNA probe using gated nanoporous anodic alumina.
}

\author{
Luís Pla, ${ }^{1,2,3}$ Elisabet Xifré-Pérez, ${ }^{4}$ Àngela Ribes, ${ }^{1,2,3}$ Elena Aznar, ${ }^{1,3}$ M. Dolores Marcos, ${ }^{1,2,3}$ Lluís F. \\ Marsal, ${ }^{4 \star}$ Ramón Martínez-Máñez ${ }^{1,2,3 \star}$ Félix Sancenón ${ }^{1,2,3 *}$
}

\begin{abstract}
A nanoporous anodic alumina (NAA)-based sensor system for the detection of Mycoplasma has been developed through the implementation of "molecular gates" selective to the presence of this bacterium. The capped support showed a negligible cargo release, while presence of Mycoplasma genomic DNA resulted in rhodamine $B$ fluorescent dye release. This sensor system presents a limit of detection (LOD) of 20 genomic DNA copies $\mu \mathrm{L}^{-1}$ and was applied to the detection of Mycoplasma bacteria in competitive environments, such as culture cell media.
\end{abstract}

Mycoplasma is a small bacterium (diameter $0.2 \mu \mathrm{m}$ ) without cell wall, immune to common antibiotic, capable of passing through bacterial filters and of great importance because of its common presence in cell cultures in clinical, research and biopharmaceutical industry. ${ }^{1}$ Besides, Mycoplasma is also related with the development of important pathologies such as pneumonia, rheumatoid arthritis, cancer and non-gonococcal urogenital diseases, among others..$^{2-6}$

Historically, polymerase chain reaction (PCR) methods and culture-based approaches have been extensively used for Mycoplasma detection. However, and even-though these methods are very sensitive, they have several drawbacks such as high cost, the need of trained personnel and relatively large time to obtain results. ${ }^{7}$ As an alternative, the design of new sensing systems for Mycoplasma sensing that overcome the cited drawbacks are of importance and have been recently described. Some of them use gold nanoparticles ${ }^{8}$ or multi-walled carbon nanotubes ${ }^{9,10}$ decorated with antibodies. Other methods are based on immunoassays coupled with $\mathrm{Fe}_{3} \mathrm{O}_{4}$ magnetic nanoparticles ${ }^{11}$ or use $\mathrm{Ag}$ nanorods as biosensing platform for surface enhanced Raman spectroscopy analysis. ${ }^{12}$

From another point of view, we and others have proposed recently the use of mesoporous organic-inorganic gated supports as suitable materials for the development of new recognition and sensing protocols. In a typical design, a mesoporous silica support is loaded with a dye/fluorophore and

[1] L. Pla, Dr. M. D. Marcos, À. Ribes, Dr. E. Aznar, Prof. R. MartínezMáñez, Dr. F. Sancenon.

Departamento de Química, Universidad Politécnica de Valencia

Camino de Vera s/n, 46022, Valencia, Spain

E-mail:rmaez@qim.upv.es

[2] L. Pla, À. Ribes, Dr. M. D. Marcos, Prof. R. Martínez-Máñez, Dr. F. Sancenon.

Instituto Interuniversitario de Investigación de Reconocimiento Molecular y Desarrollo Tecnológico (IDM), Universitat Politécnica de Valencia, Universitat de Valencia.

[3] À. Ribes, Dr. E. Aznar, Dr. M.D. Marcos, Prof. R. Martínez-Máñez, Dr. F. Sancenon.

CIBER de Bioingeniería, Biomateriales y Nanomedicina (CIBERBBN).

[4] E. Xifré-Pérez, Prof. LI. Marsal.

Departamento de Ingeniería Electrónica, Eléctrica y Automática, Universidad Rovira i Virgili, Avda. Paissos Catalans 26, 43007, Tarragona (Spain)

Supporting Information for this article is given via a link at the end of the document. the external surface of the material is functionalized with selected capping molecules able to selectively recognize a certain target analyte. These materials remain capped, until the presence of the analyte induces a displacement of the cap resulting in pore opening and delivery of the entrapped reporter. Based on that simple concept, capped mesoporous silica materials for the selective detection of certain cations, anions and biomolecules have been described recently. ${ }^{13-15}$ Moreover, in this context, we have recently reported the design of gated materials for the detection of genomic DNA from bacteria. ${ }^{16,17}$ However, studies in this filed are still rare. In our examples the capped materials were prepared using mesoporous silica nanoparticles as inorganic support. However, silica nanoparticles presented certain drawbacks such as difficult handling, can be harmful if skin deposited or breathed and usually have an intrinsic difficulty of forming uniform suspensions that may hamper to obtain highly reproducible sensing systems.

In this context, we were interested in explore the possible use of other porous scaffolds to design gated materials for sensing applications and selected nanoporous anodic alumina (NAA). NAA is a competitive support in nanotechnology that has been used for a significant number of different applications. ${ }^{18-21}$ Preparation of NAA is easy and easily up scalable by using wellknown techniques. ${ }^{22,23}$ Moreover, NAA is stable, biocompatible and does not degrade in aqueous solutions, which may contribute to the development of robust reproducible devices. ${ }^{21,24}$ Finally, it was also considered that NAA can be calcined and reused which may prolong the support's lifespan.

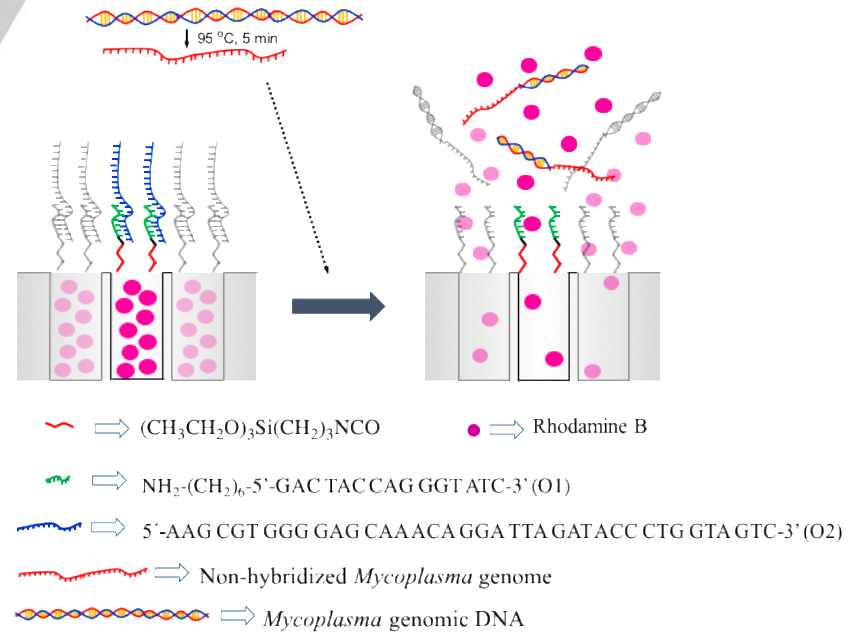

Scheme 1. Schematic representation of S3 material capped with a double strand DNA. Delivery of the entrapped dye (rhodamine B) is selectively achieved in the presence of Mycoplasma genomic DNA.

Taking into account the above-mentioned facts, we report herein a new hybrid gated material based on NAA and capped with a double stranded oligonucleotide sequence for the fluorogenic detection of Mycoplasma fermentans genomic DNA 
A schematic representation of the gated support is shown in Scheme 1. NAA supports have been recently used for the preparation of electrochemical DNA sensors. ${ }^{25-30}$ In these sensors, oligonucleotides sequences are grafted in the inner of the pores of the NAA support and hybridization with certain DNA sequences controlled the access of an electrochemical marker to the electrode surface. In our approach, oligonucleotides are grafted onto the external surface of the alumina support and the presence of certain DNA (i.e. Mycoplasma fermentans genomic DNA) control the delivery of dye molecules entrapped in the pores.

NAA was prepared following reported procedures. ${ }^{22-24}$ The pores of the NAA support were loaded with rhodamine B and, afterward, an excess of (3-isocyanatopropyl)triethoxysilane was added in order to functionalize the external surface with isocyanatopropyl moieties (solid S1). Then, oligonucleotide 01, functionalized with an aminohexyl moiety at the 5'-end position (i.e. $\mathrm{NH}_{2}-\left(\mathrm{CH}_{2}\right)_{6}-5^{\prime}-\mathrm{GAC}$ TAC CAG GGT ATC-3'), was anchored onto $\mathbf{S 1}$ through the formation of urea bonds yielding solid $\mathbf{S 2}$. The final material $\mathbf{S 3}$ was prepared by hybridization of oligonucleotide 02 (5'-AAG CGT GGG GAG CAA ACA GGA TTA GAT ACC CTG GTA GTC-3' which is a highly conserved sequence of the $16 \mathrm{~S}$ ribosomal subunit in Mycoplasma species genome), with sequence 01 grafted in the external surface of solid S2 (see Supporting Information for further details).

Table 1. Organic matter contents $\left(\alpha\right.$ in $\left.\mathrm{mmol} \mathrm{g}^{-1}\right)$ for the different prepared supports.

\begin{tabular}{lllll}
\hline & $\alpha_{\text {Rh B }}$ & $\alpha_{\text {isocyanate }}$ & $\alpha_{\mathrm{O} 1}$ & $\alpha_{\mathrm{O} 2}$ \\
\hline S1 & 0.67 & 0.01 & & \\
S2 & 0.25 & 0.01 & 0.1 & \\
S3 & 0.24 & 0.01 & 0.1 & 0.11 \\
\hline
\end{tabular}

NAA, S1, S2 and S3 supports were characterized using field scanning electron microscopy (FESEM). As can be seen in Figure 1a, NAA support presented a disordered pore distribution with an average pore diameter of ca. $8 \mathrm{~nm}$. Upon loading of the pores with rhodamine $\mathrm{B}$, functionalization with isocyanatopropyl moieties, grafting of $\mathbf{0 1}$ oligonucleotide and subsequent hybridization with $\mathbf{0 2}$ a dense organic layer in most of the NAA surface can be observed (see Figure $1 \mathrm{~b}$ for the final $\mathbf{S 3}$ support). Besides, the porous framework of the NAA scaffold was preserved after the different loading and functionalization steps as can be seen in Figure $1 \mathrm{~b}$ that shows a small part in $\mathbf{S 3}$ in which the organic layer was absent and the disordered porous network was observed. Furthermore, powder X-ray diffraction studies of the different prepared supports were carried out confirming that the support does not present an ordered pore distribution (see Supporting Information). Moreover, from thermogravimetric analyses, contents of organic matter for the different prepared supports were determined (see Table 1).

The response of S3 was tested in the absence and in the presence of Mycoplasma fermentans genomic DNA by measuring the emission of rhodamine $\mathrm{B}$ dye at $585 \mathrm{~nm}\left(\lambda_{\mathrm{ex}}=\right.$ $555 \mathrm{~nm}$ ) delivered from the pores of the NAA support. In a typical experiment, two independent S3 samples were submerged in $1.0 \mathrm{~mL}$ of TRIS buffer ( $\mathrm{pH} 7.4)$. At the same time, a solution of 5000 copies $\mu^{-1}$ of Mycoplasma fermentans quantification standard in water was heated to $95^{\circ} \mathrm{C}$ for $5 \mathrm{~min}$ (in order to dehybridize the double helix structure) and then cooled on an ice bath for $3 \mathrm{~min}$.

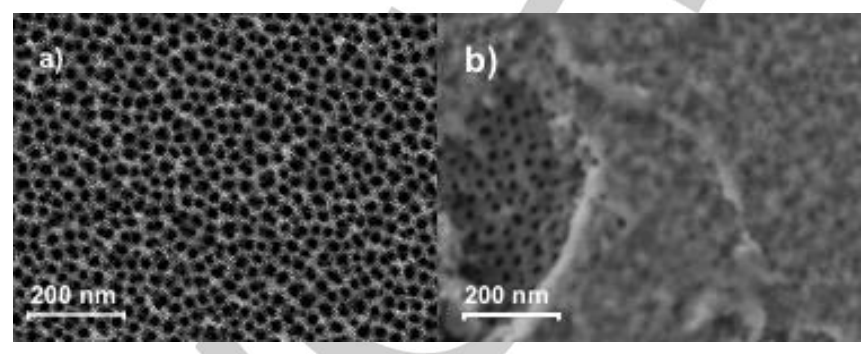

Figure 1. Representative FESEM images of (a) NAA scaffold and (b) S3.

After cooling, $50 \mu \mathrm{L}$ of Mycoplasma fermentans genomic DNA solution was added to one of the supports whereas $50 \mu \mathrm{L}$ of water were added to the other. Both solutions were maintained at $25^{\circ} \mathrm{C}$ and aliquots were taken at scheduled times. Cargo release was then determined by the emission of the rhodamine $B$ dye in the solution. As shown in Figure 2, in the absence of Mycoplasma fermentans genomic DNA a low payload release was found (ca. $15 \%$ of the total dye delivered after $60 \mathrm{~min}$ ) indicating an effective pore closure, whereas in the presence of Mycoplasma genomic DNA, a marked rhodamine B delivery was observed. This release was ascribed to pore opening due to the displacement of $\mathbf{0 2}$ from $\mathbf{S} 3$ support in the presence of genomic DNA.

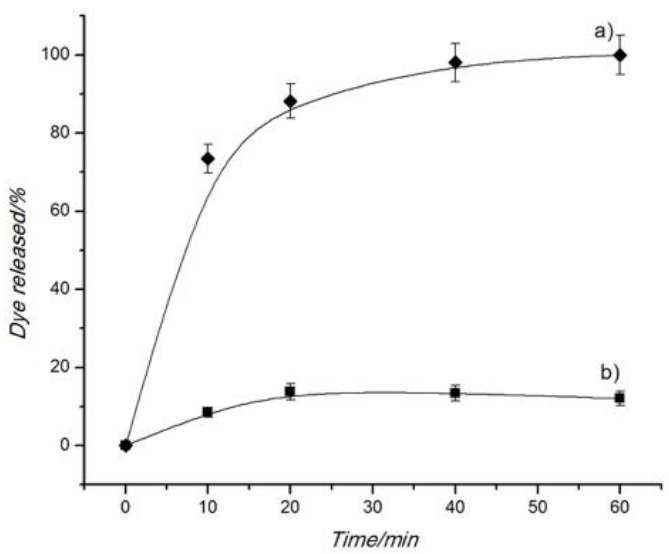

Figure 2: Release of rhodamine B from S3 support (b) in the absence and (a) in the presence of Mycoplasma fermentans genomic DNA (100 copies $\mu \mathrm{L}^{-1}$ ) in TRIS buffer at $\mathrm{pH} 7.4$.

In a second step, a study of the response of S3 to different concentrations of Mycoplasma genomic DNA was carried out. Following a similar procedure to that shown above, solutions containing different concentrations of Mycoplasma fermentans genomic DNA were added to several $\mathbf{S 3}$ supports in $1 \mathrm{~mL}$ of TRIS buffer and the rhodamine $B$ released from the support was measured after $60 \mathrm{~min}$. As seen in Figure 3, a clear correlation between the number of copies of Mycoplasma genomic DNA 
added and dye released from $\mathbf{S 3}$ was found. This observation is in agreement with the uncapping protocol shown in Scheme 1 and linked with the displacement of $\mathbf{O 2}$ from $\mathbf{S} 3$ support. A limit of detection (LOD) as low as 20 DNA copies $\mu \mathrm{L}^{-1}$ was determined from Figure 3. Besides, the LOD we have found is not far from those reported for commercially available PCR Mycoplasma detection kits (ca. 10 copies $\mu^{-1}$ ) suggesting the potential use of $\mathbf{S} 3$ supports in real applications.

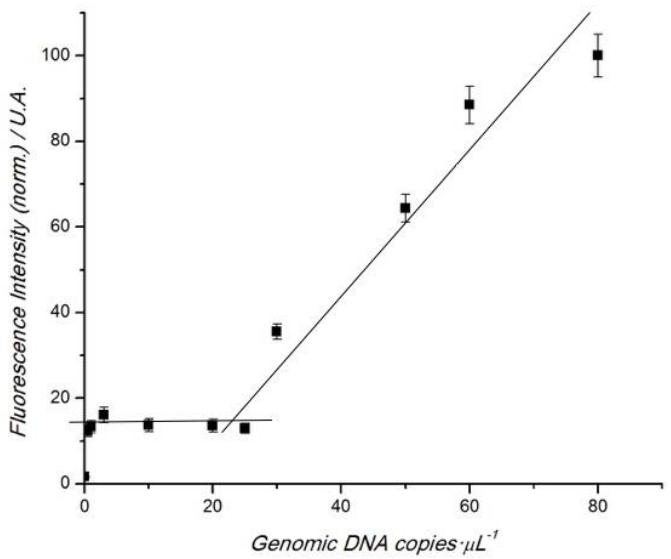

Figure 3. Release of rhodamine $B$ in TRIS buffer ( $\mathrm{pH} 7.4$ ) from support $\mathbf{S} 3$ in the presence of different Mycoplasma fermentans genomic DNA copies.

Additionally, selectivity in the detection of Mycoplasma using S3 was investigated by carrying out similar delivery experiments in the presence of other genomic DNA. For this purpose, the response of $\mathbf{S} 3$ with of Legionella pneumophila and Candida albicans genomic DNA (1000 copies $\left.\mu \mathrm{L}^{-1}\right)$ was studied. As seen in Figure 4 there were no significant differences between the blank (cargo release in TRIS buffer) and experiments in the presence of genomic DNA of Legionella or Candida. There was neither delivery of the entrapped dye when a mixture of Legionella pneumophila and Candida albicans (each one at a concentration of 1000 copies $\mu \mathrm{L}^{-1}$ ) was used. As a clear contrast, when Mycoplasma genomic DNA was present a clear delivery of rhodamine $B$ was observed. These experiments demonstrated that $\mathbf{S} 3$ is selectively opened in the presence of Mycoplasma genomic DNA.

Stimulated by these results, we decided to take a step forward and test the possible application of S3 solid for the qualitative detection of Mycoplasma species in real contaminated biological media. For this purpose, we selected MDA-MB-231 breast cancer cell media contaminated and not with Mycoplasma (previously confirmed by PCR studies). Two different S3 supports were submerged in $1 \mathrm{~mL}$ of the cell media with and without Mycoplasma contamination and the emission intensity of rhodamine $B$ released at $585 \mathrm{~nm}$ was measured after $60 \mathrm{~min}$. The obtained results are shown in Figure 5. As can be seen, a clear difference in payload released from $\mathbf{S 3}$ was found. When using cell media contaminated with Mycoplasma a marked rhodamine B delivery was observed, which was not found in uncontaminated samples, strongly suggesting the potential use of the NAA capped probe for the detection of this bacteria in real environments.

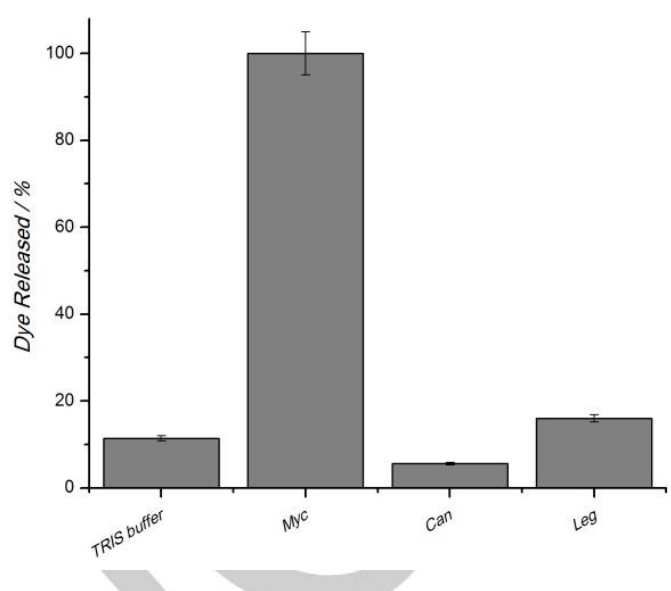

Figure 4. Release of rhodamine B from S3 support in the presence of (from left to right): TRIS buffer, Mycoplasma fermentans (Myc), Candida albicans (Can), Legionella pneumophila (Leg) genomic DNA. All DNA used were in a concentration of 1000 copies $\mu \mathrm{L}^{-1}$

Finally, the possible recycling of the NAA support was tested. For this purpose, an already used support was calcined at $550 \stackrel{\circ}{ } \mathrm{C}$ for 5 hours to eliminate the organic matter, and then functionalized again following the same process described above. This yielded solid S3-R1. On the other hand, another already used support S3 (in which $\mathbf{0 2}$ was displaced and rhodamine $B$ cargo delivered), was again loaded with rhodamine $B$ and then capped with oligonucleotide $\mathbf{0 2}$, yielding S3-R2 Both reused supports were able to release rhodamine $B$ in the presence of Mycoplasma genomic DNA (see Supporting Information) suggesting the possible easily reutilization of the NAA support.

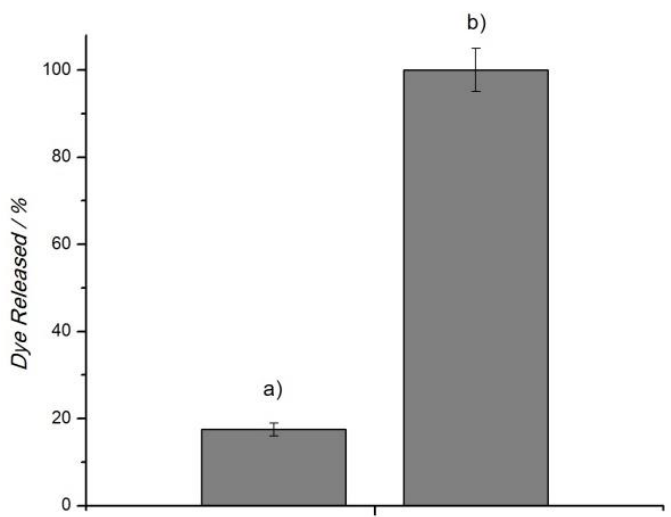

Figure 5. Release of rhodamine B from support S3 submerged in MDA-MB231 breast cancer cell line extract (a) without and (b) with Mycoplasma contamination. The emission of rhodamine B released was measured after $1 \mathrm{~h}$ of $\mathbf{S} \mathbf{3}$ immersion into cell media.

In summary, we reported here the use of NAA as inorganic support for the preparation of sensing materials for the sensitive and selective detection of Mycoplasma fermentans genomic DNA. Pores of NAA were loaded with rhodamine $B$ and capped with a covalently linked double stranded DNA containing a highly conserved sequence of the $16 \mathrm{~S}$ ribosomal subunit of 
Mycoplasma species genome. In the presence of Mycoplasma fermentans genomic DNA a marked delivery of the entrapped dye was observed. A LOD of ca. 20 DNA copies $\mu \mathrm{L}^{-1}$ was determined. Besides, genomic DNA of Legionella pneumophila and Candida albicans were unable to induce pore opening and cargo delivery. Furthermore, it was demonstrated the effective use of S3 for the detection of Mycoplasma in contaminated culture media without any complex sample pretreatment. The probe is very simple to prepare, easy to handle, reusable, does not require trained personnel and has high potential for the selective and sensitive detection of Mycoplasma in real environments.

\section{Acknowledgements}

We thank the Spanish Government (projects MAT2015-64139C4-1-R, AGL2015-70235-C2-2-R, and TEC2015-71324-R (MINECO/FEDER, UE)), the Generalitat Valenciana (project PROMETEOII/2014/047), the Catalan authority (project AGAUR 2014SGR1344), and ICREA under the ICREA Academia Award for support. L.P. thanks to PROMETEOII/2014/047 for his contract. The authors also thank the Electron Microscopy Service at the UPV for support.

Keywords: Nanoporous anodic alumina, gated materials, DNA, Mycoplasma detection

[1]. C. D. Helgason, C. L. Miller in Basic Cell Culture Protocols, 4th ed. (Eds.: Springer Protocols, Methods in Molecular Biology), 2013.

[2]. L. Matas, S. Molinos, G. Fernández, V. González, V. Ausina, Enferm. Infecc. Microbiol. Clin. 2006, 24, 19-23.

[3]. V. Ausina, Infecciones causadas por Micoplasmas (Eds.: Medicina Interna Elsevier España), 2004; Chapter 15, pp 2362-2365.

[4]. S. Tsai, D. J. Wear, J. W. Shiht, S. C. Lo, Proc. Natl. Acad. Sci. 1995, 92, 10197-10201.

[5]. J. Y. Ning, C. C. Shou, Chin. J. Cancer 2004, 23, 602604.

[6]. M. B. Rogers, Oncotarget, 2011, 2, 271-273.

[7]. C. M. Nüblinga, S. A. Baylisa, K.-M. Hanschmanna, T. Montag-Lessinga, M. Chudya, J. Kreßa, U. Ulrychb, S. Czurdab, R. Rosengartenb, Appl. Environ. Microbiol. 2015, 81, $5694-5702$.

[8]. K. Meng, W. Sun, P. Zhao, L. Zhang, D. Cai, Z. Cheng, H. Guo, J. Liu, D. Yang, S. Wang, T. Chai, Bioelectron. 2014, 55, 396-399.

[9]. H. Fayazfar, A. Afshar, M. Dolati, A. Dolati, Anal. Chim. Acta 2014, 836, 34-44.

[10]. L. Zhang, C. Z. Huang, Y. F. Li, S. J. Xiao, J.P. Xie, J. Phys. Chem. B 2008, 112, 7120-7122.

[11]. M. Yang, Y. Guan, Y. Yang, T. Xia, W. Xiong, C. A. Guo, Mater. Lett., 2014, 137, 113-116.

[12]. K. C. Henderson, E. S. Sheppard, O. E. RiveraBetancourt, J. -Y. Choi, R. A. Dluhy, K. A. Thurman, J.
M. Winchell, D. C. Krause, Analyst 2014, 139, 64266434.

[13]. a) Z. Wang, X. Yang, J. Feng, Y. Tang, Y. Jianga, N. He, Analyst 2014, 139, 6088-6091; b) LI. Pascual, S. El Sayed, R. Martínez-Máñez, A. M. Costero, S. Gil, P. Gaviña, F. Sancenón, Org. Lett. 2016, 18, 5548-5551; C) R. Bhat, A. Ribes, N. Mas, E. Aznar, F. Sancenón, M. D. Marcos, J. R. Murguía, A. Venkataraman, R. Martínez-Máñez, Langmuir 2016, 32, 1195-1200; d) S. El Sayed, M. Milani, M. Licchelli, R. Martínez-Máñez, F. Sancenón, Chem. Eur. J. 2015, 21, 7002-7006; e) M. Oroval, E. Climent, C. Coll, R. Eritja, A, Aviñó, M. D. Marcos, F. Sancenón, R. Martínez-Máñez, P. Amorós, Chem. Commun. 2013, 49, 5480-5482.

[14]. F. Sancenón, L. Pascual, M. Oroval, E. Aznar, R. Martínez-Máñez, ChemistryOpen 2015, 4, 418-437.

[15].E. Aznar, M. Oroval, L. Pascual, J. R. Murguía, R. Martínez-Máñez, F. Sancenón, Chem. Rev. 2016, 116 (2), 561-718.

[16]. E. Climent, L. Mondragón, R. Martínez-Máñez, F. Sancenón, M. D. Marcos, J. R. Murguía, P. Amorós, K. Rurack, E. Perez-Payá, Angew. Chem. Int. Ed. 2013, 52, $8938-8942$.

[17]. L. Pascual, I. Baroja, E. Aznar, F. Sancenón, M. D. Marcos, J. R. Murguía, P. Amorós, K. Rurack, R. Martínez-Máñez, Chem. Commun. 2015, 51, 14141416.

[18]. G. Macias, L. P. Hernańdez-Eguía, J. Ferre-Borrull, J. Pallares, L. F. Marsal, ACS Appl. Mater. Interfaces 2013, 5, 8093-8098.

[19]. T. Kumeria, M. M. Rahman, A. Santos, J. Ferré-Borrull, L. F. Marsal, D. Losic, Anal. Chem. 2014, 86, 18371844.

[20]. T. Kumeria, M. M. Rahman, A. Santos, J. Ferre, L. F. Marsal, D. Losic, ACS Appl. Mater. Interfaces 2014, 6, 12971-12978.

[21]. E. Xifre-Perez, S. Guaita-Esteruelas, M. Baranowska, J. Pallares, L. Masana, L. F. Marsal, ACS Appl. Mater. Interfaces 2015, 7, 18600-18608.

[22]. L. Vojkuvka, L. F. Marsal, J. Ferré-Borrull, P. Formentin, J. Pallarés, Superlattices Microstruct. 2008, 44, 577-582.

[23]. A. Santos, P. Formentín, J. Ferré-Borrull, J. Pallarès, L. F. Marsal, Mater. Lett. 2012, 67, 296-299.

[24]. L. F. Marsal, L. Vojkuvka, P. Formentin, J. Pallarés, J. Ferré-Borrull, Opt. Mater. 2009, 31, 860-864.

[25]. V. Rai, J. Deng, C. -S. Toh, Talanta 2012, 98, 112-117.

[26]. A. de la Escosura-Muñiz, A. Mercoçi, Trends Anal. Chem. 2016, 79, 134-150.

[27]. A. Santos, T. Kumeria, D. Losic, Trends Anal. Chem. 2013, 44, 25-38.

[28]. L. Wang, Q. Liu, Z. Hu, Y. Zhang, C. Wu, M. Yang, P. Wang, Talanta 2009, 78, 647-652.

[29]. P. Takmakov, I. Vlassiouk, S. Smirnov, Analyst 2006, $131,1248-1253$ 
[30].S. -J. Li, J. Li, K. Wang, C. Wang, J. -J. Xu, H. -Y. Chen, X. -H. Xia, Q. Huo, ACS Nano 2010, 4, 6417

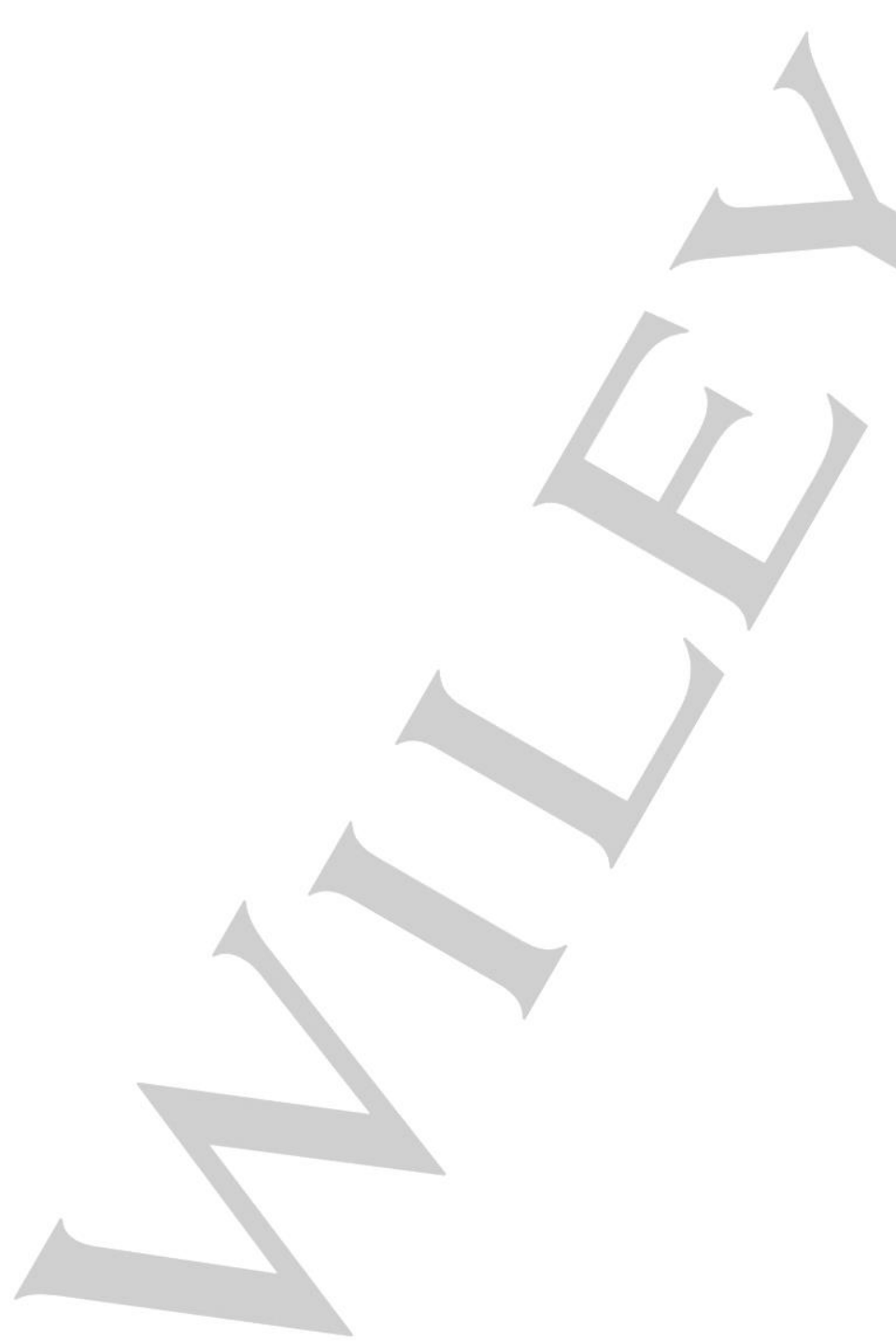




\section{COMMUNICATION}

A nanoporous anodic alumina (NAA)based sensor system for the detection of Mycoplasma has been developed. The capped support showed a marked rhodamine $B$ release in the presence of Mycoplasma genomic DNA. The capped support presents a LOD of 20 genomic DNA copies $\mu \mathrm{L}^{-1}$ and was applied successfully to the detection of Mycoplasma in competitive environments.

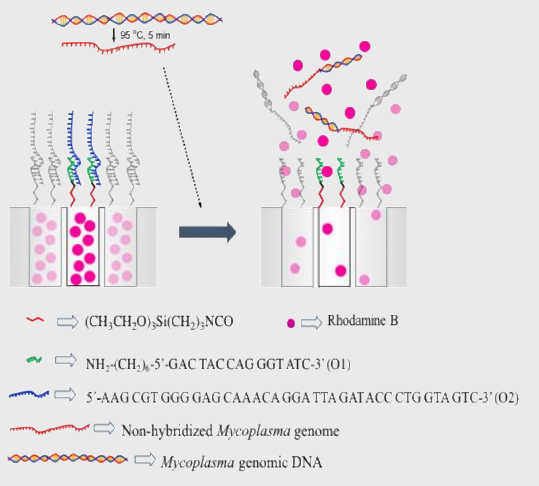

Luís Pla, Elisabet Xifré-Pérez, Elena Aznar, M. Dolores Marcos, Lluís F.

Marsal, Ramón Martínez-Máñez, Félix Sancenón.

Page No. - Page No.

A Mycoplasma genomic DNA probe using gated nanoporous anodic alumina. 